\title{
The Effect of Fish Oil and Omega-3 Fatty Acid on Some Physiological and Biochemical Criteria in Male Rabbits
}

\author{
Israa Seger Salman \\ Department of Biology, College of Science for women, Baghdad University.
}

\begin{abstract}
Fish oil and omega-3 have many benefits and effects on human and animals health, such heart diseases, lipids, liver and many other diseases, so the aim of the this study was to investigate the effect of fish oil and omega-3 on complete blood picture test (CBC), Lipid profile, some liver enzymes and kidney parameters in male rabbits. Twelve adult male rabbits were used in this study that divided into two groups: (Six rabbits for each group) and treated daily for 4 weeks.

Group 1: $0.2 \mathrm{ml} / \mathrm{Kg} \mathrm{B.W}$ fish oil dose orally.

Group 2: $0.2 \mathrm{ml} / \mathrm{Kg} \mathrm{B}$.W omega-3 dose orally.

Blood samples were collected and divided from both two groups at the end of the experiment and then parameters were measured. Results explained that fish oil and omega- 3 had the same effect in male rabbits. The level of complet blood picture $(\mathrm{CBC})$ showed a significant decrease $(\mathrm{p}<0.05)$, but did not go beyond the normal reference value. The study explained that there were significant reduction in total cholesterol, serum triacylglycerol (TAG), serum low density lipoprotein (LDL) and very low density lipoprotein (VLDL) while the high density lipoprotein (HDL) was elevated significantly as compared with control. Significant increase in serum level of glutamic oxalic transaminase (GOT) and glutamic pyruvic transferees (GPT) in fish oil and omega-3 treated animals as compared with the control. While the effect of fish oil and omega-3 on kidney parameters (Uric acid, Creatinine) showed non-significant changes or a slight increase significant in kidney parameters as compared with the control. [DOI: 10.22401/JNUS.20.1.015]
\end{abstract}

Keywords: Fish oil, Omega-3, Liver enzymes, Kidney parameters, Lipid profile.

\section{Introduction}

Fish oils are unique fats because they are rich sources of n-3 fatty acids (FAS) and they are polyunsaturated fat that contain many compounds that including omega-3 fatty acids [1]. These compounds are not only in fish but also in many organisms like plants, the major omega-3 in fish oil that are eciosapentaenoic acid (EPA, (20:5)) and decosahexaenoic acid (DHA(22:6)) [2].

Fish oil and omega-3 have many important benefits like they entered in a good feeding and treated for many diseases as they decrease rheumatoid arthritis [3].They have benefits in preventing cardiovascular disease, and the protection of heart from risk as Heart attack and sudden cardiac death[2]. Besides, omega-3 has important as anti-thrombotic, antiinflammatory effects and it reduces in platelets and endothelial cells[4].

Recent modern studies showed that omega3 could down regulate the activity of the nuclear factor (NF-kß) [5] that plays a key role in the regulation of gene expression in inflammatory responses and has been implicated in the pathogenesis of CVD[6]. In addition, the importance of omega-3, fish oil also contains omega- 6 that plays role in a healthy body provided that the ratio between these compounds are balanced, it means a higheromega- 6 and a lower omega- 3 intake there was a balance between them. Their balance is an important determination for brain and in decreasing the risk for coronary heart disease (CHD), Hypertension, cancer and Diabetes [7]. Both EPA and DHA complete with arachidonic acid (omega-6) in cyclooxygenase and lipoxygenesis synthesis, resulting in net anti-inflammatory effects. Both reduce blood viscosity without a significant positive effects on blood lipids, most consistently a reduction in triglyceride concentration[8]. Both fish oil and omega-3 have hypolipidemic effect [9].

The purpose of the this study is to investigate the effect of fish oil and omega-3 on the complete blood picture $(\mathrm{CBC})$, lipid 
profile, some liver enzymes and kidney function parameters in male rabbits.

\section{Subjects and methods \\ 1- Experimental animals}

Twenty healthy adult male rabbits (1200$1800 \mathrm{~g}$ ) were kept in the animal house of Department of Biology at the College of Science for Women, University of Baghdad provided with food and water. Twelve adult male rabbits were randomly divided into two groups kept for 2 weeks for adaptation, (12 rabbits/group) and handled as follows for 30 days: *Before they divided, animals in this group before starting the experiment blood was collected part was used for hematological study with EDTA anticoagulants and part for biochemical study and considered as control group (Before treated).Treated group was divided into groups $(\mathrm{n}=6)$ as follows:

A- Group 1: 6 Rabbits were administered with $0.2 \mathrm{ml}$ fish oil orally by gavages needle.

B-Group 2: 6 Rabbits were administered with $0.2 \mathrm{ml}$ omega- 3 orally by gavages needle.

\section{2- Preparation of fish oil and omega-3}

Fish oil was prepared from Valamugil seheli known as mullet fish, where fish cleaned and removed the scales then it was put in oven at less than $60 c^{\circ}$ to get oils. Oils was collected in test tubes, while omega- 3 plus was purchased from local pharmacy of Vitex Pharmaceuticals in Australia(1000mg natural fish oil).

\section{Blood sampling}

Blood samples were collected from fasting animals at Zero time (Before supplementation) and at the end of experiment (after 30 days), Blood was drawn by heart puncture technique from rabbit. Each blood sample was divided into two parts:

1- Aliquot of $0.2 \mathrm{ml}$ of blood was kept in heparin tube for complete blood picture (CBC). It is measured in Mindray BC2800(Korea, Japan, China).

2- Another part of blood was kept in gel and clot activator tube not more than 4 hours, followed by centrifugation for 15 minutes at 4000rpm. Serum was isolated and kept in eppendorf tubes frozen at $-20 \mathrm{C}^{\circ}$ until analysis to study some biochemical and parameters like:

A-Lipid profile measured by enzymatic method with commercially available kit (HUMAN Germany) [10], [11],[ 12],[ 13], [14] sequentially:

1- Total cholesterol (TC) concentration (mg/dl).

2- Triacylglycerol (TG) concentration $(\mathrm{mg} / \mathrm{dl})$.

3- High density lipoprotein-cholesterol $(\mathrm{HDH}-\mathrm{C})$ concentration $(\mathrm{mg} / \mathrm{dl})$.

4- Low density lipoprotein-cholesterol (HDH-C) concentration $(\mathrm{mg} / \mathrm{dl})$.

5- Very low density lipoproteincholesterol (HDH-C) concentration (mg/dl).

B-1-Liver enzymes :A- Aspartic or Glutamic oxaloacetic Transaminase AST or GOT activity (IU/l), B- Glutamic pyruvic Transaminase GPT activity (IU/l) [15]. C- Alkaline Phosphatase ALP activity (IU/l))[16].

2-Kidney parameters:

A- Uric acid concentration $(\mathrm{mg} / \mathrm{dl})(16)$.

B- Creatinine concentration $(\mathrm{mg} / \mathrm{dl})[17]$.

\section{Statistical Analysis}

The Statistical Analysis System- SAS (2012)[18] program was used to find out the effect of difference factors on studyed parameters. Least significant difference-was used to compare between means.

\section{Results and Discussion}

Tables (1) and (2) showed that male rabbits intubated omega-3 and fish oil, exhibited significant decrease in $\mathrm{RBCs}, \mathrm{Hb}, \mathrm{HCT} \%$, WBCs and Plt as compared with control (Before treatment). These results agree with Abbas (2013)[19], Harris (2003) [20] and Daak, etal (2013)[21]. The decrease in RBC, $\mathrm{Hb}$, HCT may due to a decrease in erythropioesis and thus haemolysis [22]. While the decrease in Plt due to antithrombo effect of omega 3 and fish oil that is rich with omega3 that have a vasodilatation effect on blood flow [23]. Fish oil increased WBCs, which may due to fish oil that enhanced the function of B cells [24]. 
Table (1)

The effect of Omega3 on blood picture in male rabbits.

\begin{tabular}{|c|c|c|}
\hline \multirow[b]{2}{*}{ Parameters } & \multicolumn{2}{|c|}{$\overline{\text { Mean } \pm \text { SE }}$} \\
\hline & $\begin{array}{c}\text { Control } \\
\text { (Before treatment) }\end{array}$ & $\begin{array}{c}\text { Omega treatment } \\
\text { (After treatment }(30 \text { days }) \text { ) }\end{array}$ \\
\hline R.B.C x $10^{12}$ & $6.49 \pm 0.11$ & $5.17 \pm 0.04 *$ \\
\hline $\mathrm{Hb}(\mathrm{g} / \mathrm{dl})$ & $13.83 \pm 0.13$ & $11.00 \pm 0.15^{*}$ \\
\hline HCT (\%) & $42.58 \pm 0.54$ & $34.61 \pm 0.52 *$ \\
\hline W.B.C x $10^{9}$ & $7.16 \pm 0.18$ & $9.15 \pm 0.43^{*}$ \\
\hline PLT x $10^{9}$ & $257.33 \pm 5.57$ & $165.13 \pm 3.75^{*}$ \\
\hline
\end{tabular}

Values expressed as mean \pm SE $n=6$.

Table (2)

The effect of fish oil on blood picture in male rabbits.

\begin{tabular}{|c||c|c||}
\hline \multirow{2}{*}{ Parameters } & \multicolumn{2}{|c|}{ Mean \pm SE } \\
\cline { 2 - 3 } & $\begin{array}{c}\text { Control } \\
\text { (Before treatment) }\end{array}$ & $\begin{array}{c}\text { Fish oil treatment } \\
\text { (After treatment (30 days)) }\end{array}$ \\
\hline \hline R.B.C x 10 & $6.30 \pm 0.12$ & $5.22 \pm 0.16^{*}$ \\
\hline \hline $\mathrm{Hb}(\mathrm{g} / \mathrm{dl})$ & $13.63 \pm 0.32$ & $10.83 \pm 0.20^{*}$ \\
\hline $\mathrm{HCT}(\%)$ & $41.25 \pm 0.76$ & $34.76 \pm 0.71^{*}$ \\
\hline \hline W.B.C $\times 10^{9}$ & $9.05 \pm 0.48$ & $8.67 \pm 0.08 \mathrm{NS}$ \\
\hline \hline PLT $\times 10^{9}$ & $318.75 \pm 30.62$ & $251.42 \pm 16.63 \mathrm{NS}$ \\
\hline \hline & $*(\mathrm{P}<0.05), \mathrm{NS}:$ Non-significant. \\
\hline
\end{tabular}

Values expressed as mean \pm SE $n=6$.

Tables (3) and (4) showed that animals treated that omega-3 and fish oil, exhibited a significant decrease in TAG, TC, LDL-C, VLDL-C. The hypolipidimic effect of omega3 and fish oil may due to suppression of hepatic lipogensis [25] and also omega3 have an important role by regulating genes that are controlling lipid homeostasis resulting in lower triacylglycerol concentration [26]. These results agreed with Simopoulos (1991) [27] and Abbas (2013)[19] found that omega-3 reduced plasma cholesterol and TAG concentration by inhibiting biosynthesis of very low-density lipoproteins (VLDL) and triglycerides in the liver. Also, they reported decrease in cholesterol and LDL level, a marked a decrease in $\mathrm{TG}$ and no change in HDL level or increases [9]. As well as, [28] found that omega-3 fatty acids decreased in serum triacylglycerol, LDL and VLDL of all treated diabetic rats with omega- 3 for 8 weeks suffered from increasing lipid profile level in diabetic rats without omega 3 treatment. 
Table (3)

The effect of Omega 3 on Lipid profile in male rabbits.

\begin{tabular}{|c|c|c|}
\hline \multirow[b]{2}{*}{ Parameters } & \multicolumn{2}{|c|}{ Mean $\pm \mathrm{SE}$} \\
\hline & $\begin{array}{c}\text { Control } \\
\text { (Before treatment) }\end{array}$ & $\begin{array}{c}\text { Omega treatment } \\
\text { (After treatment (30 days)) }\end{array}$ \\
\hline Cholesterol Total $(\mathrm{mg} / \mathrm{dl})$ & $89.83 \pm 0.40$ & $78.83 \pm 0.74 *$ \\
\hline $\begin{array}{l}\text { Triglyceride (TAG) } \\
\text { (mg/dl) }\end{array}$ & $58.83 \pm 2.77$ & $45.16 \pm 1.70 *$ \\
\hline HDL(mg/dl) & $39.30 \pm 0.52$ & $39.65 \pm 0.82 *$ \\
\hline LDL(mg/dl) & $44.52 \pm 0.20$ & $30.42 \pm 1.83^{*}$ \\
\hline VLDL(mg/dl) & $11.76 \pm 0.55$ & $9.02 \pm 0.31 *$ \\
\hline
\end{tabular}

Values expressed as mean $\pm \mathrm{SE} n=6$.

Table (4)

The effect of fish oil on Lipid profile in male rabbits.

\begin{tabular}{|c||c|c||}
\hline \multirow{2}{*}{ Parameters } & \multicolumn{2}{c|}{ Mean \pm SE } \\
\cline { 2 - 3 } & $\begin{array}{c}\text { Control } \\
\text { (Before treatment) }\end{array}$ & $\begin{array}{c}\text { Fish oil treatment } \\
\text { (After treatment (30 days) }\end{array}$ \\
\hline \hline Cholesterol(mg/dl) Total & $101.58 \pm 2.11$ & $83.00 \pm 3.00^{*}$ \\
\hline \hline Triglyceride(TAG) $(\mathrm{mg} / \mathrm{dl})$ & $64.16 \pm 3.21$ & $45.50 \pm 1.25^{*}$ \\
\hline \hline HDL(mg/dl) & $36.11 \pm 0.67$ & $39.45 \pm 0.51^{*}$ \\
\hline \hline LDL(mg/dl) & $51.80 \pm 1.65$ & $38.13 \pm 3.91^{*}$ \\
\hline VLDL(mg/dl) & $12.83 \pm 0.64$ & $9.10 \pm 0.25^{*}$ \\
\hline
\end{tabular}

Values expressed as mean $\pm \mathrm{SE} n=6$.

The results of the present study explained that the effect of omega3 and fish oil on liver enzyme (GOT, GPT, ALP) and kidney parameters (Uric acid, Creatinine) as shown in Tables (5) and (6) increased GOT, GPT with in Uric acid concentration in omega3 treated male rabbits as compared with control, while in fish oil intubated male rabbits there was significant increase in GOT, GPT and creatinin. Some results agree with Mohammed, etal [29] and Assad, etal [30].

Table (5)

The effect of Omega3 on Liver enzymes and Kidney parameters in male rabbits.

\begin{tabular}{|c|c|c|c|c|c|}
\hline Para. & GOT (U/ml) & GPT(U/ml) & $\begin{array}{c}\text { ALP } \\
(\mathrm{U} / \mathrm{ml}) \\
\end{array}$ & $\begin{array}{c}\text { Creatinine } \\
(\mathrm{mg} / \mathrm{dl})\end{array}$ & $\begin{array}{c}\text { Uric acid } \\
(\mathrm{mg} / \mathrm{dl})\end{array}$ \\
\hline $\begin{array}{l}\text { Control (Before } \\
\text { treatment) }\end{array}$ & $23.67 \pm 1.05$ & $\begin{array}{c}42.00 \pm \\
1.59\end{array}$ & $\begin{array}{c}121.00 \pm \\
2.36\end{array}$ & $\begin{array}{c}0.423 \pm \\
0.01\end{array}$ & $\begin{array}{c}47.66 \pm \\
0.67\end{array}$ \\
\hline $\begin{array}{c}\text { Treated (After } \\
\text { treatment (30 days)) }\end{array}$ & $28.67 \pm 1.78 *$ & $\begin{array}{l}49.33 \pm \\
2.60^{*}\end{array}$ & $\begin{array}{l}117.00 \pm \\
4.27 \mathrm{NS}\end{array}$ & $\begin{array}{l}0.478 \pm \\
0.03 N S\end{array}$ & $\begin{array}{l}36.67 \pm \\
2.23^{*}\end{array}$ \\
\hline
\end{tabular}

Values expressed as mean $\pm \mathrm{SE} n=6$. 
Table (6)

The effect of Omega3 on Liver enzymes and Kidney parameters in male rabbits.

\begin{tabular}{|c|c|c|c|c|c|}
\hline Para. & GOT (U/ml) & GPT(U/ml) & $\begin{array}{c}\text { ALP } \\
(\mathrm{U} / \mathrm{ml}) \\
\end{array}$ & $\begin{array}{c}\text { Creatinine } \\
(\mathrm{mg} / \mathrm{dl})\end{array}$ & $\begin{array}{c}\text { Uric acid } \\
(\mathrm{mg} / \mathrm{dl}) \\
\end{array}$ \\
\hline $\begin{array}{c}\text { Control (Before } \\
\text { treatment) }\end{array}$ & $20.16 \pm 0.47$ & $\begin{array}{c}41.17 \pm \\
1.49\end{array}$ & $\begin{array}{c}115.67 \pm \\
2.57\end{array}$ & $\begin{array}{c}0.470 \pm \\
0.02\end{array}$ & $\begin{array}{c}42.67 \pm \\
1.33\end{array}$ \\
\hline $\begin{array}{c}\text { Treated (After } \\
\text { treatment (30 days)) }\end{array}$ & $\begin{array}{c}25.83 \pm \\
1.49^{*}\end{array}$ & $\begin{array}{c}49.83 \pm \\
1.17 * \\
\end{array}$ & $\begin{array}{l}120.67 \pm \\
2.20 \mathrm{NS} \\
\end{array}$ & $\begin{array}{c}0.606 \pm \\
0.03^{*}\end{array}$ & $\begin{array}{l}39.00 \pm \\
2.08 \mathrm{NS}\end{array}$ \\
\hline
\end{tabular}

Values expressed as mean \pm SE $n=6$.

\section{Conclusion}

The conclusion of this study explained that the omega-3 and fish oil have a hypolipidimic effects, an immunenhancer by increasing the number of white blood cells, significant decrease in platelet count and significant decrease in uric acid in omega3 treated rabbits as compared with control.

\section{References}

[1] Harris, W.S. Omega-3 fatty acids and cardiovascular disease: A case for omega-3 index as a new risk factor. Pharmacological Research, 55: 217-223. 2007.

[2] Lands, W.E. Biochemistry and physiology of n-3 fatty acids. The FASEB Journal, 6:530-2356. 1992.

[3] Kremer, J. M. N-3 fatty acid supplements in rheumatoid arthritis. Am J. clinical. Nutrition, 71(1): 3495- 3515. 2000.

[4] Geleijnse, JM.; Gitay, EJ.; Grobbee, DE.; Donders, ART. and Kok,FJ. Blood pressure response to fish oil supplementation: Metaregression analysis of randomized trials. J. Hypertens, 20: 14931499. 2002.

[5] Adlins, Y.K. Mechanisms underlying the cardioprotective effects of omega-3 polyunsaturated fatty acids. J Nutr. Biochem, 21:781- 792. 2010.

[6] Winther, MP.; Kanters, E.; Krall, G. and Hofker, MH. NF-kß singling in atherogensis. Aterioscler Thromb Vasc Biol, 25: 904-914. 2005.

[7] Simopoulos, A.P. The omega-3/ omega-6 fatty acid ratio: health implications. Ocl. J, 17(5):267. 2010.

[8] Calder, PC. N-3 fatty acids and cardiovascular disease. Evidence explained and mechanisms explored. Clin. SCi, 107: 1-11. 2004.
[9] Harris, W.S. Fish oils and plasma lipid and lipoprotein metabolism in humans: a critical review, Journal of lipid Reseach, 30: 785- 807. 1989.

[10] Richmond, w. Analytical reviews in clinical biochemistry the quantitative analysis of cholesterol. Ann. Clin. Bio chem., 29: 577-597. 1992.

[11] Buccolo, G. and David, H. Quantitative determination of serum triglyceride by the use of enzyme. Clin. chem., 19(5): 476-482. 1973.

[12] Finley, P.R.; Shifman, R.B.; Williams, R.S. and Lichti, D.I. Clin. Chem., 24: 931. 1971.

[13] Friedewald, W.; Levy, Y. and Fredrickson. Estimation of the concentration of low- density lipoprotein cholesterol in plasma without use of preparative ultracentrifuge. Clin. Chem.., 18: 499-502. 1972.

[14] International Federation of clinical chemistry (IFCC). Clin. Chem.. lab. Med, 36: 185. 1998.

[15] German Society for clinical chemistry. Recommendations of the enzyme commission. Z. clin. Chem. Biochem, 10: 281. 1972.

[16] Fossati, Precipel, L. and Berti, O. Clin. Chem., 26: 227. 1980.

[17] Heinegaard, D. and Tinderstom, G. Clin. Chem. Acta, 43: 305. 1973.

[18] SAS. Statistical Analysis system, Users Guide. Statistical. Version 9. 1th ed .SAS. Inst. Inc. Cary. N. C. USA. 2012.

[19] Abbas, M.M. Physiological effect of omega-3 unsaturated fatty acids in healthy subjects. Nature and science, 11(7): 14-18. 2013. 
[20] Harris, W.s. N-3 long chain polyunsaturated fatty acids reduce risk of coronary disease death: extending the evidence to the eldery. American Journal of clinical Nutrition, 71: 279- 280. 2003.

[21] Daak, A. A.; Ghebremeskel, K.; Hassan, Z.; Attallah, B.; Azan, H.H.; Elbashir, M.I. and Crawford, M. Effect of omega-3 (n-3) fatty acid supplementation in patients with sickle cell anemia: randomized, doubleblind, placebo-controlled trial. Am J.clin Nur, 97: 37-44. 2013.

[22] Mohammed, B.A.; Elzubeir, A. M.M.; Elmahdi, T. E.E.; Addak, A.A. and Abdelfarag, M.M. Assessment the effect of omega-3 fatty acid supplementation in Sudanese patients with sickle cell Anemia; Khartoum, Sudan. International Journal of Multidisciplinary and current Research, 2: 2321- 13124. 2014.

[23] Ruxton, CH.; Calder, PC.; REED, SC. And Simpson, MJ. The impact of long chain n-3 polyunsaturated fatty acids on human health. Nutr Res Rev, 18: 113-129. 2005.

[24] Gurzell, E, A.; Teague, H.; Harris, M.; Clinthores, J.; Shaikh, S, R. and Fenton, J, I. DHA-enriched fish oil targets B cell lipid microdomains and in vivo and ex vivo $B$ cell function.JLB,93(4):463-470. 2013.

[25] Strolien, H.H.; Kriketos, A.D.; Calver, G.D.; Daur, L.A. and Jenkis, A.B. Fatty acids, Triglycerides and plasma lipid and lipoprotein Metabolism in human: Acritical Review, Diabetes care, 30(4): 1012-1024. 2007.

[26] Sampath, H. and Ntambi, JM. Polyunsaturated fatty acid regulation of genes of lipid metabolism. Annu Rev Nutr, 25: 317- 340. 2005.

[27] Simopoulos, A.P. Omega-3 fatty acids in health and disease and in growth and development: Am.J. clin. Nutr, 54(3): 438463. 1991.

[28] Soltan, S.S.A.M. The effect of varieties sources of omega-3 fatty acids on Diabetes in Rats. Food and Nutrition Science, 3: 1404-1412. 2012.

[29] Mohammed, S.S.; Mohammed, S.R. and El-Sedeek, L.E. The omega-3 ecosa and decosa polyunsaturated long chain fatty acids have a potent effect to protect liver and kidney toxicity in Rats. International Journal of Academic Research, 4(2): 169. 2012.

[30] Asaad, H.R. and Aziz, FM. Protective of omega-3 fish oil against the toxicity of Ifosfamide in male Rats. JJBS,5(1): 37-46. 2012.

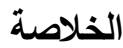

يحوي زيت السمك والحامض الدهني اوميغا ب على الكثير من الفوائد والتاثيرات على صحة الانسان والحيوانات مثل امراض القلب والدهون والكبد والكثير من الامراض الاخرى. لذلك كان الهدف من الدراسة معرفة ناثثر زيت السمك والحامض الدهني اوميغا ب على اختبار الصورة الكاملة للام والدهون وعلى بعض انزيمات الكبد ووظائف الكلى في ذكور الارانب. استعملت في هذه التجربة اثثا عشر ولثر

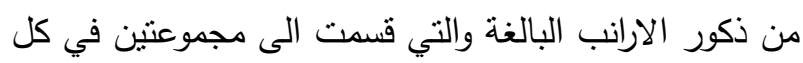
مجموعة ست ارانب وتم معاملتها يوميا لمدة اربعة اسابيع.

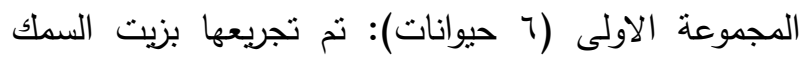
بمقدار 0.2 ملم/كغم فمويا. المجموعة الثانية (؟ حيوانات): تم تجريعها بالحامض الدهني اوميغاس بمقدار 0.2 ملم/كغم

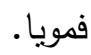

جمعت وقسمت العينات من المجموعة في نهاية التجربة ومن ثم قيست العينات. اوضحت النتائج ان زيت السمك في نهابه والحامض الدهني لهما نفس التاثير في ذكور الفئران البيض اذا كان هناللك انخفاض معنوي بمستوى احتمالية (0.05) في مستوى معاير الدم. اوضحت الدراسة هناللك انخفاض معنوي (p<0.05) في مستويات الدهون في الدم والتي مئي شملت Total cholesterol, serum triacylglycerol (TAG), serum low density lipoprotein (LDL) مع and very low density lipoprotein (VLDL) very low من مسنوى ارتفاع معنوي 0.05 > density lipoprotein (VLDL)

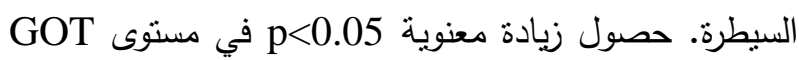
و و بالمقارنة مع مجموعة السيطرة.اما فيما يخص ناثير زيت السمك والوميغا r في مؤشرات الكلية فلم يلاحظ اي بـاي تغيرات معنوية p>05 او زيادة معنوية قليلة جدا بالمقارنة مع مجموعة السيطرة. 